\title{
Antioxidant and antimicrobial activities of Callistemon comboynensis essential oil
}

\author{
Mohamed I. Abdelhady a,b* and Hamdy A. H. Aly \\ ${ }^{a}$ Department of Pharmacognosy, Faculty of Pharmacy, Umm Al-Qura University, Makkah, P.O. Box 715, Saudi Arabia; \\ ${ }^{b}$ Pharmacognosy Department, Faculty of Pharmacy, Helwan University, Cairo, Egypt; \\ ${ }^{c}$ Environmental Biotechnology Department, Genetic Engineering and Biotechnology Research Institute (GEBRI), \\ Sadat city - Menofia University - Egypt. P.O. Box 79.
}

\section{ABSTRACT}

Introduction: The genus Callistemon is known in folk medicine for its anticough, antibronchitis, and insecticidal effects and its volatile oils have been used as antimicrobial and antifungal agents. Methods: The essential oils obtained by hydrodistillation of the leaves of Callistemon comboynensis $(C c)$ was investigated by GC/MS. Antioxidant activity of $C c$ was investigated using 1,1-diphenyl-2-picrylhydrazyl (DPPH). The antimicrobial activity of the essential oil of $C c$ was evaluated against both gram positive (Bacillus subtilis and Staphylococcus aureus), gram negative (Proteus vulgaris, Pseudomonas aeruginosa) and a pathogenic fungus Candida albicans. Results: It was found that $C c$ afford $0.22 \%$ volatile oil. The major components of the volatile oil of $C c$ are 1, 8-cineol (53.03\%), eugenol (12.1\%), methyl eugenol $(9.2 \%)$ and $\alpha$-pinene $(8.3 \%)$. The oil had pronounced antibacterial and antifungal activities on all the tested microbes. Nevertheless, $C c$ leaf oil extract exhibited high antioxidant activity $(91.1 \pm 0.3 \%)$ at a concentration of $1000 \mu \mathrm{g} \cdot \mathrm{ml}^{-1}$, comparable to $100 \mu \mathrm{g} \cdot \mathrm{ml}^{-1}$ gallic acid $(95.7 \pm 2)$.

Key Words: C. comboynensis, essential oil, cineole, antioxidant, and antimicrobial activity.

\section{INTRODUCTION}

The genus Callistemon (commonly named bottle brush) comprises about 25 species belong to the family Myrtaceae, which are widely cultivated and much used as ornamental shrubs in California, and in warm countries and in green houses ${ }^{[1]}$. The genus Callistemon is known in folk medicine for its anticough, antibronchitis, and insecticidal effects ${ }^{[2,30]}$ and its volatile oils have been used as an antimicrobial ${ }^{[3,4]}$ and antifunga ${ }^{[5]}$ agents. The oil of $C$. lanceolatus was reported as antifungal ${ }^{[6]}$ and $C$. citratus, $C$. viridiflorous and $C$. pendulous as antifungal and antimicrobial ${ }^{[7,8]}$. Additionally, the oil of C. lanceolatus shows insecticidal activity ${ }^{\left[{ }^{[}\right]}$. Essential oils of some Callistemon species have been chemically examined i.e. C. lanceolatus (syn. C. citrinus) $)^{[9-12]}$, C. viminalis ${ }^{[9,13]}$, C. speciosus ${ }^{[14]}$, C. rigidus ${ }^{[15-17]}$ and $C$. linearis ${ }^{[29]}$. In all cases 1,8-cineole has been reported as their major constituent with varying amounts,

*Address for correspondence:

E-mail:mohibrahem@yahoo.com and miabdelhady@uqu.edu.sa

DOI: $10.5530 / a x .2012 .2 .8$ while $\beta$-pinene represents the major constituent incase of C. polandii ${ }^{[28]}$, and methyl eugenol represents the major constituent incase of $C$. viridiflorous ${ }^{[25]}$. The present communication reports on the leaf oil composition of C. comboynensis grown in Egypt for the first time. Also it reports the antioxidant and antimicrobial activities of the volatile oil.

\section{MATERIAL AND METHODS}

\section{Plant material}

Ccleaves were collected from Alexandria-Cairo road, Egypt in April 2011. Identification of the plant was confirmed by Dr. Trease Labeb, senior specialized of plant taxonomy, Orman garden, Giza, Egypt as well as by comparison with reference herbarium specimens.

Material for testing the antimicrobial and antioxidant activities

Gram positive bacteria (Bacillus subtilis NCTC6633 and Staphylococcus aureus ATCC4175), gram negative bacteria 
(Proteus vulgaris NCTC4175 and Pseudomonas aeruginosa CNCMA21) and yeast (Candida albicans ATCC60193) were supplied from Microbiology department, faculty of science, Beni-suif University. DPPH (1,1-diphenyl-2-picrylhydrazyl; Sigma-Aldrich, St. Louis, MO, USA).

\section{Standard antimicrobial agents}

Ofloxacin and Amphotricin B antibiotics ready discs (5 ug/disc) used as positive control.

\section{METHODS}

Preparation of the essential oil

Freshly comminuted leaves of $C c$ was separately hydrodistilled for 6 hours in a Clevenger type apparatus. The resulting oils were collected, dried over anhydrous sodium sulphate and stored under refrigeration until analysis. Percentage yields were determined according to the Egyptian Pharmacopoeia, 1984 ${ }^{[24]}$.

\section{G.C/MS for volatile oil}

G.C analyses were performed on a GC/MS system (SHIMADZU GC/MS-QP5050A) with software (Class 5000). Gas chromatograph equipped with a fused silica column (DB5.25 $\mathrm{m} \times 0.53 \mathrm{~mm}$ i.d; $1.5 \mathrm{um}$ film thickness). The analyses were carried out under the following conditions: Carrier gas: He with flow rate $2 \mathrm{ml} / \mathrm{min} ; 280^{\circ} \mathrm{C}$; Detector temp. FID: $280^{\circ} \mathrm{C}$; Injector temp.: $250^{\circ} \mathrm{C}$; split ratio; $1: 10$; Oven temp. Program: initial temp.; $40^{\circ} \mathrm{C}(0.5 \mathrm{~min})$ increasing to $150{ }^{\circ} \mathrm{C}$ (at $\left.7.5^{\circ} \mathrm{C} / \mathrm{min}\right), 150^{\circ} \mathrm{C}(1 \mathrm{~min})$ then increasing to $250^{\circ} \mathrm{C}$ (at $\left.5{ }^{\circ} \mathrm{C} / \mathrm{min}\right)-250^{\circ} \mathrm{C}(2 \mathrm{~min})$. The capillary column was directly coupled with a quadrupole mass spectrometer (QP5050A). EI-MS were recorded at $70 \mathrm{ev}$. The analysis has been done in the Analytical biotechnology unit, the regional centre for Mycology and Biotechnology, Alazhar University, Cairo, Egypt. Identification of the components were performed by aid of the computer library search (Class 5000 lab software package) comparison of mass spectra with literature data and by comparison of their retention times and mass fragmentation patterns with those of the library data base (Wiley (Wiley Int. USA)) $)^{[31-33]}$.

\section{Biological study}

The anti-microbial activity of the volatile oil was carried out in the Microbiology department, faculty of science, Beni-suif University, applying the disc agar diffusion method $^{[26]}$. The oil was diluted with DMSO at concentration 1:5 v/v, then $20 \mu \mathrm{l}$ ( $4 \mathrm{ul}$ of pure oil/disc) was aseptically transferred onto sterile discs of Whatmann filter paper (5 mm diameter).
Evaluation of the antioxidant activity

Determination of the free radical scavenging activity of the different extracts was carried out using a modified quantitative assay ${ }^{[53]}$. Various concentrations of sample oil extract in methanol were prepared $(1000,500,250$, and $100 \mu \mathrm{g} / \mathrm{ml})$. Gallic acid was used as a positive control at concentrations of $100,50,25$, and $10 \mu \mathrm{g} / \mathrm{ml}$. Blank samples were run using $1 \mathrm{ml}$ methanol in place of the test extract. One $\mathrm{ml}$ of $0.2 \mathrm{mM}$ DPPH in methanol was added to $1 \mathrm{ml}$ of the test solution or standard plus $1 \mathrm{ml}$ of methanol for dilution and allowed to stand at room temperature in a dark chamber for $30 \mathrm{~min}$. The change in color from deep violet to light yellow was then measured at $517 \mathrm{~nm}$. Inhibition of free radical in percent (I \%) was calculated according to the following equation: $\mathrm{I} \%=[(\mathrm{A} 0-\mathrm{A} 1) / \mathrm{A} 0] \mathrm{X} 100$, with A0 being the absorbance of the control reaction (containing all reagents except for the extract) and A1 the absorbance of the extract. Measurements were carried out in triplicates

\section{RESULTS AND DISCUSSION}

Essential oil was obtained by hydrodistillation of the leaves of $C c$ which yielded 0.22 was analyzed by GC/MS. Qualitative and quantitative variations of the components in $C c$ are compiled in table (1). GC-MS analysis of the oil under the experimental conditions revealed the presence of 23 components in $\mathrm{Cc}$ leaves.

This oil is dominated by oxygenated compounds $90.22 \%$. In the same time, the hydrocarbon contents are small $(8.48 \%)$. Previous studies ${ }^{[9-28]}$ on the composition of the oil from leaves of other Callistemon species showed that 1,8 -cineole is the main component in those species between (45-80\%), while $\beta$-pinene represents the major constituent in case of $C$. polandii, methyl eugenol incase of $C$. viridiflorous. In the present study it was observed that 1,8-cineole (53.03\%) is the main component in $C_{c}$ followed by eugenol (12.1\%), methyl eugenol $(8.3 \%), \alpha$-terpineol $(4.3 \%)$ then carveol (3.4\%). It was interesting to know that $C c$ produces high amount of cineole, eugenol and methyl-eugenol as previous studies observed that those compounds are potent naturally occurring antimicrobial agent against broad spectrum of microorganisms and antifungal activity and it has also nematocidal activity and have a good antioxidant activities ${ }^{[25,34-38,39-42]}$. This directed the study to think about the influence of the volatile oil on the growth of certain microorganisms and as antioxidant activity.

The antimicrobial screening showed that oils under investigation exhibited broad spectrum effect against 
gram-positive, gram-negative and yeast (table 2). The highest antimicrobial activity was observed against Staphylococcus aureus $(107 \%$ that of OFX) and Proteus vulgaris $(102 \%$ of that OFX) for volatile oil of $C c$. The oil of $C c$ possessed a moderate activity against Bacillus subtilis $(88 \%$ of that $\mathrm{OFX})$ and Pseudomonas aeruginosa (80\% of that $\mathrm{OFX})$ and for Candida albicans (77\% that of Amp B). This activity may be attributed to the higher content of oxygenated constituents $(90.22 \%)$.

Antioxidants play an important role in the prevention of human diseases. Antioxidant compounds may function as free radical scavengers, complexing agents for pro-oxidant metals, as well as reducing agents and quenchers of singlet oxygen formation ${ }^{[43,44,51,54]}$.
It is well known that there is a strong relationship between total phenol content and antioxidant activity, as phenols possess strong scavenging ability for free radicals due to their hydroxyl groups. Therefore, the phenolic content of plants may directly contribute to their antioxidant action $^{[45-47,52] \text {. }}$

The standardized Callistemon extracts were assessed for their capacity to scavenge DDPH free radical along with gallic acid as a positive control. The antioxidant activity data are presented as percent of free radical inhibition in Table (3). The oil extract from leaves of $C c$ exhibited pronounced antioxidant activity $(91.1 \pm 0.3 \%)$ at a concentration of $1000 \mu \mathrm{g} / \mathrm{ml}$, comparable to $100 \mu \mathrm{g} / \mathrm{ml}$ gallic acid $(95.7 \pm$ $2 \%$ ). It was previously reported that non- phenolic

Table 1: Results of GC/MS analysis of the volatile oils of $C$. comboynensis

\begin{tabular}{|c|c|c|c|}
\hline Identified compounds & Retention time (min) & $\mathbf{M}^{+}$ & C. comboynensis $\%$ \\
\hline 2-hydroxy-pentamide & 4.947 & 117 & 0.2 \\
\hline Heptylhydroperoxide & 5.690 & 132 & 0.33 \\
\hline B-pinene & 6.433 & 136 & 0.12 \\
\hline Myrcene & 7.453 & 136 & 0.06 \\
\hline Linalyl acetate & 8.734 & 196 & 0.15 \\
\hline 1,8-cineol & 9.234 & 154 & 53.03 \\
\hline a-terpinolene & 10.431 & 136 & 0.7 \\
\hline Linalool & 10.853 & 154 & 1.1 \\
\hline$\alpha$-Terpineol & 11.134 & 154 & 4.3 \\
\hline Carveol & 11.764 & 152 & 3.4 \\
\hline Citronellal & 11.973 & 156 & 0.4 \\
\hline Maltol & 12.327 & 126 & 0.1 \\
\hline Geraniol & 12.842 & 154 & 2.2 \\
\hline Alpha pinene & 12.983 & 136 & 8.3 \\
\hline Citronellyl acetate & 13.254 & 206 & 0.14 \\
\hline Neryl acetate & 13.546 & 196 & 1.4 \\
\hline Cyclopentylmethyl ketone & 13.949 & 112 & 0.1 \\
\hline Verbanone & 14.266 & 150 & 0.2 \\
\hline p-Propenylanisole & 14.556 & 148 & 0.75 \\
\hline Eugenol & 15.461 & 164 & 12.1 \\
\hline Dihydrocarvyl acetate & 16.415 & 196 & 0.2 \\
\hline Methyl-Eugenol & 18.756 & 178 & 9.2 \\
\hline ß-Copaen & 21.112 & 204 & 0.22 \\
\hline Identified compounds & & & 98.7 \\
\hline Unidentified compounds & & & 1.3 \\
\hline Hydrocarbons & & & 8.48 \\
\hline Oxygenated compounds & & & 90.22 \\
\hline
\end{tabular}

Table 2: results of antimicrobial activity of the essential oil of the leaves $C$. Comboynensis

\begin{tabular}{|c|c|c|c|}
\hline \multirow{2}{*}{ Tested microorganisms } & \multicolumn{3}{|c|}{ Diameter of zone of inhibition $(\mathrm{mm})$} \\
\hline & Of essential oil of C. comboynensis & OFX & AMP B \\
\hline Staphylococcus aureus ATCC 4175 & $31(107 \%)$ & $29(100 \%)$ & - \\
\hline Bacillus subtilis NCTC 6633 & $28(88 \%)$ & $32(100 \%)$ & - \\
\hline Proteus vulgaris NCTC 4175 & $30.5(102 \%)$ & $30(100 \%)$ & - \\
\hline Pseudomonas aeruginosa CNCMA21 & $16(80 \%)$ & $20(100 \%)$ & - \\
\hline Candida albicans ATCC 60193 & $17(77 \%)$ & - & $22(100 \%)$ \\
\hline
\end{tabular}

OFX, Ofloxacin; AMP B, Amphotricin B; -, no inhibition zone. 
Table 3: Antioxidant activity of Cc volatile oil extract assayed by the DPPH assay

\begin{tabular}{lccc}
\hline Gallic acid & $\begin{array}{c}\text { Conc. of } \\
\text { standard } \boldsymbol{\mu g} / \mathbf{m l}\end{array}$ & Cc & $\begin{array}{c}\text { Conc. of } \\
\text { extract } \boldsymbol{\mu g} / \mathbf{m l}\end{array}$ \\
\hline $95.7 \pm 2$ & 100 & $91.1 \pm 0.3$ & 1000 \\
$86.7 \pm 0.7$ & 50 & $87.4 \pm 0.4$ & 500 \\
$78.3 \pm 0.5$ & 25 & $70.8 \pm 0.4$ & 250 \\
$66.4 \pm 0.2$ & 10 & $62.6 \pm 0.7$ & 100 \\
\hline
\end{tabular}

Activity is expressed as inhibition of free radical in percent, $I \% \pm S D(n=3)$. Leaf and cell culture extracts were tested at 1000,500, 250 and $100 \mu \mathrm{g} / \mathrm{ml}$ and the positive control (gallic acid) at 100, 50, 25 and $10 \mu \mathrm{g} / \mathrm{ml}$.

antioxidants might also contribute to the antioxidant activity of plant extracts ${ }^{[5,51]}$. Thus, compounds other than phenolics might be responsible for the pronounced antioxidant activity observed with $C c$ oil, which requires further investigation. The responsible constituents in the Callistemon species under study have to be identified and characterized. Phenolic compounds are also believed to have chemo preventive and suppressive activities against cancer cells by inhibition of metabolic enzymes involved in the activation of potential carcinogens or arresting the cell cycle ${ }^{[50]}$. Nevertheless, a compound with strong antioxidant potential can also contribute to DNA protection and prevent apoptosis ${ }^{[54]}$. In a previous comparative study of Tamoxifin (a synthetic antiestrogen) and methyl eugenol it was found that they have antitumor effect in case of breast cancer with restricted doses, because at higher doses they cause mutation of DNA leading to increase susceptibility to cause liver tumor ${ }^{[34]}$. It was reported that chronic oral intake of high dose levels of methyl eugenol was associated with increased of hepatotoxicity and liver and stomach neoplasma in rats and mice ${ }^{[34,36]}$. Further study of the effect of the volatile oil of C.comboynensis as a natural source of cineole, eugenol and methyl eugenol may open the way to treat the breast cancer with no side effects (i.e. herbal medicine). Further studies will therefore be done to detect potential anticancer activity of the extracts reported here.

\section{REFERENCES}

1. Bailey, L. H. Mannual of cultivated Plants., The Macmillan company, New York; 1958. p 725.

2. Ndomo F., Tapondjou1 L. A., Ngamo L. T. and T. Hance T. Insecticidal activities of essential oil of Callistemon viminalis applied as fumigant and powder against two bruchids. J. Appl. Entomol. 2010; 134:333-41

3. Opeoluwa O. Oyedeji , Oladipupo. A. Lawal, Francis. O. Shode and Adebola. O. Oyedeji. Chemical Composition and Antibacterial Activity of the Essential Oils of Callistemon citrinus and Callistemon viminalis from South Africa. Molecules 2009; 14, 1990-98

4. Yusuf M., Chowdhury J.U., Wahab M.A. Medicinal Plants of Bangladesh. J. Sci. Ind. Res. 1994; 28:25-34.

5. Pandey, A. K. Proceedings of the National Academy of Scienceses, India Sec. B 1995; 65:73.

6. Islam MR, Ahamed R, Rahman MO, Akbar MA, Al-Amin M, Alam KD, Lyzu F. In Vitro Antimicrobial Activities of Four Medicinally Important Plants in Bangladesh. Eur J Sci Res. 2010; 39:199-206.
7. Cowan, M.M. Plant products as antimicrobial agents. Clin. Microbial. Rev.1999;22:564-82

8. Riaz, M., Chaudhary F. M.. The Chemical Composition of Pakistani Callistemon citrinus Oils Journal of Essential Oil Research. 1990; 2:327-28

9. Silva CJ, Barbosa LCA, Demuner AJ, Montanari RM, Pinheiro AL, Andrade NJ. Chemical composition and antibacterial activities from the essential oils of Myrtaceae species planted in Brazil. Quim Nova. 2010; 33:104-8.

10. Chane-Ming, J.; Vera, R.R.; Fraissed, J. Chemical composition of essential oil of Callistemon citrinus (Curtis) Skeel from Reunion. J. Esent. oil Res. 1998, 10, 429- 31.

11. Adonizio A L, Downum K, Bennett BC, Mathee K. Anti-quorum sensing activity of medicinal plants in southern Florida. J Ethnopharmacol. 2006;105:427-35.

12. Mahmoud, I.I.; Marzouk, M.S.A.; Moharram, J.; Nolte, J.; Fobbe, R.; Saleh, M.I. Chemical composition of the Egyptian Callistemon lanceolatus DC. and Callistemon viminalis (Gaertner loudan) oils. Bull. Fac. Pharm. 2000; 40:11219.

13. Paul I. Forster, Robert J., Goldsack A, Joseph J. Brophy. Leaf Essential Oils of the Australian Members of the Genus Callistemon (Myrtaceae). Journal of Essential Oil Research. 1998; 22:204-9

14. Oyedeji O.O., Oyedeji A. O., Shode F. O. and Lawal O. A. Volatile Constituents of the Leaf Oils of Callistemon salignus from Two Provinces in South Africa. Journal of essential oil research. 2011;11:613-15.

15. Michael M. Smyth and Erich V. Lassak. Steam Volatile Leaf Oil of Callistemon linearis (Schrader et Wendl.) Sweet. Journal of essential oil research. 1994; 6:403-6.

16. Pierre MD Jazet1, Léopold N Tatsadjieu, Bernadin D Ndongson, Jean Kuate, Paul H Amvam Zollo1 and Chantal Menut. Correlation between chemical composition and antifungal properties of essential oils of Callistemon rigidus and Callistemon citrinus of Cameroon against Phaeoramularia angolensis. Journal of Medicinal Plants Research 2009; 3:9-15.

17. Kyoko Kobayachi, Tamaki Ishihara, Eriko khono, Toshio myasi and Fumihiko Yoshizaki. Constituents of Stem Bark of Callistemon rigidus Showing Inhibitory Effects on Mouse a-Amylase Activity. Biol. Pharm. Bull. 2006; 29:1275-77

18. Sherweit A.El-Ahmady, Nahla A.Ayoub, Abdel Nasser B.Singab, Mohamed M.Al-Azizi, Karl-Heinz Kubeczka. Chemical Composition And Antimicrobial Activity Of The Essential Oils From Eucalytus Cinerea, Callistemon Viminalis and Calothamnus Quadrifidus (Myrtaceae). Trade Science Inc. 2007; 3:28-34.

19. Lounasmaa, M.; Puri, H.S.; Widen, C. Phloroglucinol derivatives of Callistemon lanceolatus leaves. Phytochemistry 1977; 16:1851-52.

20. Kobayashi, K.; Ishihara, T.; Khono, E.; Miyase, T.; Yoshizaki, F. Constituents of stem back of Callistemon rigidus showing inhibitory effects on mouse a-amylase activity. Biol. Pharmaceut. Bull. 2006; 29:1275-77.

21. Saxena, S.; Gomber, C. Antimicrobial potential of Callistemon rigidus. Pharm. Biol. 2006; 3:194-201.

22. Sunil Kumara, Vipin Kumara \& Om Prakasha. Antidiabetic, Hypolipidemic, and Antioxidant Activities of Callistemon lanceolatus Leaves Extract. Journal of Herbs, Spices \& Medicinal Plants 2011; 17:144-53.

23. Brophy, J.J.; Lassak, E.V.; Toia, R.F. The volatile leaf oils of two cultivars of Callistemon viminalis. J. Proc. R. Soc. NSW. 1986; 118:101-4

24. Egyptian Pharmacopoeia. 1984.

25. Mohamed I. S. Abdelhady. Study of free fatty acids, hydrocarbons, sterols, triterpenes and essential oil contents and the antimicrobial activity of the egyptian Callistemeon viridiflorous (sims) sweet and Callistemon rigidus R. BR. J. Union Arab Biol. Cairo 2009; 47:139-46

26. Lorian V. "Antibiotics in Laboratory Medicine" $3^{\text {rd }}$ ed., Williams and Wilkins, Hong Kong, London; 1988:134-44p.

27. Brophy, J.J.; Forster, P.I.; Goldsack, R.J.; Hibbert, D.B.; Punruckvong, A. Variation in

28. Callistemon viminalis (Myrtaceae): New Evidence from Leaf Essential Oils. Austral Syst. Bot. 1997; 10:1-13.

29. Khan M., Srivastava S. K., Syamsundar K. V. and Anju K. Yadav. Chemical composition of Callistemon polandii leaf and stem essential oils from the plains of Northern India. Chemistry of Natural Compounds. 2008; 44:807-9.

30. Srivastava, S.K.; Ahmad, A.; Jain, N.; Aggarwal, K.K.; Syamasunder, K.V. Essential oil composition of Callistemon viminalis leaves from India. Flavour Fragr. J. 2003; 13:361-63. 


\section{Antioxidant and antimicrobial activities of Callistemon comboynensis essential oil}

31. Xie Z. F.; Huang X. K. Dictionary of Traditional Chinese Medicine. Commercial Ltd., Hong Kong. 1988.

32. Guido Flamini, Pier Luigi Cioni and Ivano Morelli. Composition of the essential oils and in vivo emission of volatiles of four Lamium species from Italy L-purpureum, L-hybridum, L-bifidum and L-amplexicaule. "Food chemistry" 2005; 91:63-68.

33. Adams, R.P. "Identification of essential oil components by gas chromatography-mass spectroscopy", Allured, Carol Stream. 1995.

34. Massada, Y. "Analysis of essential oils by gas chromatography and mass spectrometry", wiley, New York. 1967.

35. Nenad Vukovic, Tanja Milosevic, Slobodan Sukdolak and Slavica Solujic Zar, J. H. Biostatistical analysis. $3^{\text {rd }}$ ed. Prentice Hall, Upper Saddle River, NJ. 2007;4:17-20.

36. William J Waddell; Neil H Crooks; Paul L Carmichael Correlation of tumors with DNA adducts from methyl eugenol and tamoxifen in rats. Toxicological sciences: an official journal of the Society of Toxicology 2004;79:38-40.

37. Christiane Ruff, Katja Hr, Bernhard Weckerle, Thorsten Knig, and Peter Schreier. Authenticity Assessment of Estragole and Methyl Eugenol by On-Line Gas Chromatography Isotope Ratio Mass Spectrometry J. Agric. Food Chem., 2002; 50:1028-31.

38. Lexa G. Matasyoh, Josphat C. Matasyoh, Francis N. Wachira, Miriam G. Kinyua, Anne W. Thairu Muigai1 and Titus K. Mukiama.2007. Chemical composition and antimicrobial activity of the essential oil of Ocimum gratissimum L. growing in Eastern Kenya. African Journal of Biotechnology 2007; 6:760-65.

39. Kwon Park, Junheon Kim, Sang-Gil Lee, Sang-Chul Shin. Nematicidal Activity of Plant Essential Oils and Components From Ajowan (Trachyspermum ammi), Allspice (Pimenta dioica) and Litsea (Litsea cubeba) Essential Oils Against Pine Wood Nematode (Bursaphelenchus Xylophilus) Journal of Nematology 2007; 39:275-79.

40. Carson, C.F.; Riley, T.V. Antimicrobial activity of the major components of the essential oil of Melalenca alternifolia. J. App. Bacteriol. 1995; 74:264-69.

41. Dilip Kumar Das. Effects of arsenic contaminated irrigation water, zinc and organic matter on the mobilization of arsenic in soils in relation to rice (Oryza sativa L.), Arsenic n Soil and Groundwater Environment (Trace metals and other Contaminants in the Environment.), First Edition, 684, Elsevier B.V, 2007; 9:339-62
42. Dutta, B. K.; Karmakar, S.; Naglot, A.; Aich, J. C.; Begam, M. Anticandidial activity of some essential oils of a mega biodiversity hotspot in India. Mycoses, 2007; 50:121-24.

43. Sharma, Rabin Kr.; Kotoky, Rumi; Bhattacharyya, Pranab R.2006. Flavour and Fragrance Journal 2006; 21:239-40.

44. Bendich A. Antioxidants, vitamins immune response In: Litwack G (Eds) Vitamins Harmones Elsevier Science, USA; 1996: p35-62.

45. Constable F, Gamborg OL, Kurz WGW, Steek W. Production of secondary metabolites in plant cell cultures. Planta Med. 1974; 25:158-65.

46. Bendini, A.; Cerretani, L.; Pizzolante, L.; Gallina-Toschi, T.; Guzzo, F.; Cedolo, F.; Andereetta, F.; Levi, M. Phenol content related to antioxidant and antimicrobial activity of Passiflora Spp. Extracts. Eur. Food Res. Technol. 2006; 223:102-9.

47. Milan S. Stankovic, Marina Topuzovic, Slavica Solujic and Vladimir Mihailovic. Antioxidant activity and concentration of phenols and flavonoids in the whole plant and plant parts of Teucrium chamaerdys L. var. glanduliferum Haussk. Journal of Medicinal Plants Research 2010; 4:2092-98.

48. Dlugosz, A.; Lembas-Bogaczyk, J.; Lamer-Zarawska, E. Antoxid increases ferric reducing antioxidant power(FRAP) even stronger than vitamin $\mathrm{C}$. Hacta Poloniae PharmH. 2006; 63:446-48.

49. Harish R, Shivanandappa T. 2006. Antioxidant activity and hepatoprotective potential of Phyllanthus niruri. Food Chem. 2006; 95:180-85.

50. Hassimotto N, Genovese M, Lajolo F. Antioxidant activity of dietary fruits, vegetables, and commercial frozen fruit pulps. J. Agric. Food Chem. 2005; 53:2928-35.

51. Newman DJ, Gragg GM, Holbeck S, Sausville EA. Natural products as leads to cell cycle pathway targets in cancer chemotherapy. Cur. Cancer Drug Targets. 2002; 2:279-308.

52. Rice-Evans, C.A.; Miller, N.J.; Paganaga, G. Antioxidant properties of phenolic compounds. Trends Plant Sci. 1997; 2:152-59.

53. Wojdylo, A.; Oszmianski, J.; Czemerys, R. Antioxidant activity and phenolic compounds in 32 selected herbs. Food Chem. 2007; 105:940-49.

54. Mensor, L. L.; Menezes, F.S.; Leitao, G.G.; Reis, A.S.; Santos, T.C.; Coube, C. S.; Leitão, S.G. . Screening of Brazilian Plant Extracts for Antioxidant Activity by the Use of DPPH Free Radical Method. Phytotherapy Research 2001;15:127-30.

55. Rajkumar V, Guha H, Kumar RA. Antioxidant and anticancer potentials of Rheum emodi rhizome extracts. eCAM; 2010:1-9. 